\title{
Middle Miocene Tonnoidea and Ficoidea (Caenogastropoda) assemblages from Letkés (Hungary)
}

\author{
Zoltán KovÁcs ${ }^{1} \&$ Zoltán VICIÁN ${ }^{2}$ \\ ${ }^{1}$ H-1077 Budapest, Wesselényi utca 52, Hungary.E-mail: kovacs.zoltan@lisztakademia.hu \\ ${ }^{2}$ H-1158 Budapest, Neptun utca 86, 10/42, Hungary.E-mail: kauri72@gmail.com
}

\begin{abstract}
Taxonomic composition of highly diverse early Badenian (early Langhian) Tonnoidea and Ficoidea assemblages from Letkés (Börzsöny Mts, Hungary) is given. Four Ficus species and 23 tonnoid species are described, including Semicassis szilviae n. sp. designated here. Four taxa represent new records from the Badenian of Hungary: Turritriton grundensis (Hoernes et Auinger), Bursa ranelloides (Reeve), Bursa corrugata (Perry), and Personopsis grasi (Bellardi in d'Ancona). Miocene stratigraphical and palaeogeographical ranges of the studied species are summarized. With 68 figures.
\end{abstract}

Key words - Badenian, Börzsöny Mts, Ficoidea, Hungary, Letkés, Middle Miocene, Tonnoidea

\section{INTRODUCTION}

The aim of this paper is to document the high alpha diversity of Tonnoidea and Ficoidea fossil assemblages from the Badenian deposits of Letkés (W Börzsöny Mts, N Hungary). The locality is situated on the slope of the Bagoly Hill about $400 \mathrm{~m}$ eastward from the village $\left(47.888319^{\circ} \mathrm{N}, 18.784647^{\circ} \mathrm{E}\right)$ (Fig. 1$)$. The geological and palaeogeographical background of the site was briefly discussed by KovÁcs \& VICIÁN (2014). The locality is characterized by resedimented beds of fossil-rich marly sand with coral blocks and andesite boulders that represent the Sámsonháza Formation (NAgYmarosy \& HÁmor 2012). The fossil assemblage shows a mixture of taxa from different biotopes, but mainly indicates shallow-water environment. Based on benthic foraminifer and gastropod index species the age of the assemblage is assigned to the early Badenian.

Cenozoic mollusc assemblages in the W Börzsöny Mts were discovered in the 1840s. Large fossil material from Letkés was first analyzed by FranzenAU (1897) who mentioned six "Cassis, Triton and Ranella" species within an assemblage of 83 gastropod species. More than 50 years later, based on new collecting works, a comprehensive revision of the Middle Miocene mollusc fauna from Szob and Letkés was published by CSEPreghy-Meznerics (1956) describing 
280 gastropod and 86 bivalve taxa. Tonnoids were represented by five species from Letkés, Ficus species was not recorded. The study was taxonomically revised as well as completed with new records by STRAUSZ (1966). After the latter monograph only a few papers dealt with the two superfamilies in the Hungarian literature (e.g. KóKay 1966; Csepreghy-Meznerics 1969a, b; BoHn-Havas 1973).

Numerous studies have treated the Miocene distribution of these groups in the Central Paratethys: e.g., Hörnes (1851-1870), Hoernes \& Auinger (1884), Boettger (1906), Kojumdgieva (1960), Hinculov (1968), AtanacKOVIĆ (1985), BA£UK (1995), PoPA et al. (2015) - for comprehensive literature see LANDAU et al. (2009).

\section{MATERIAL AND METHODS}

The materials studied here are from the collection of the Hungarian Natural History Museum, and from the private collections of Tamás Hirmetzl (Fót,

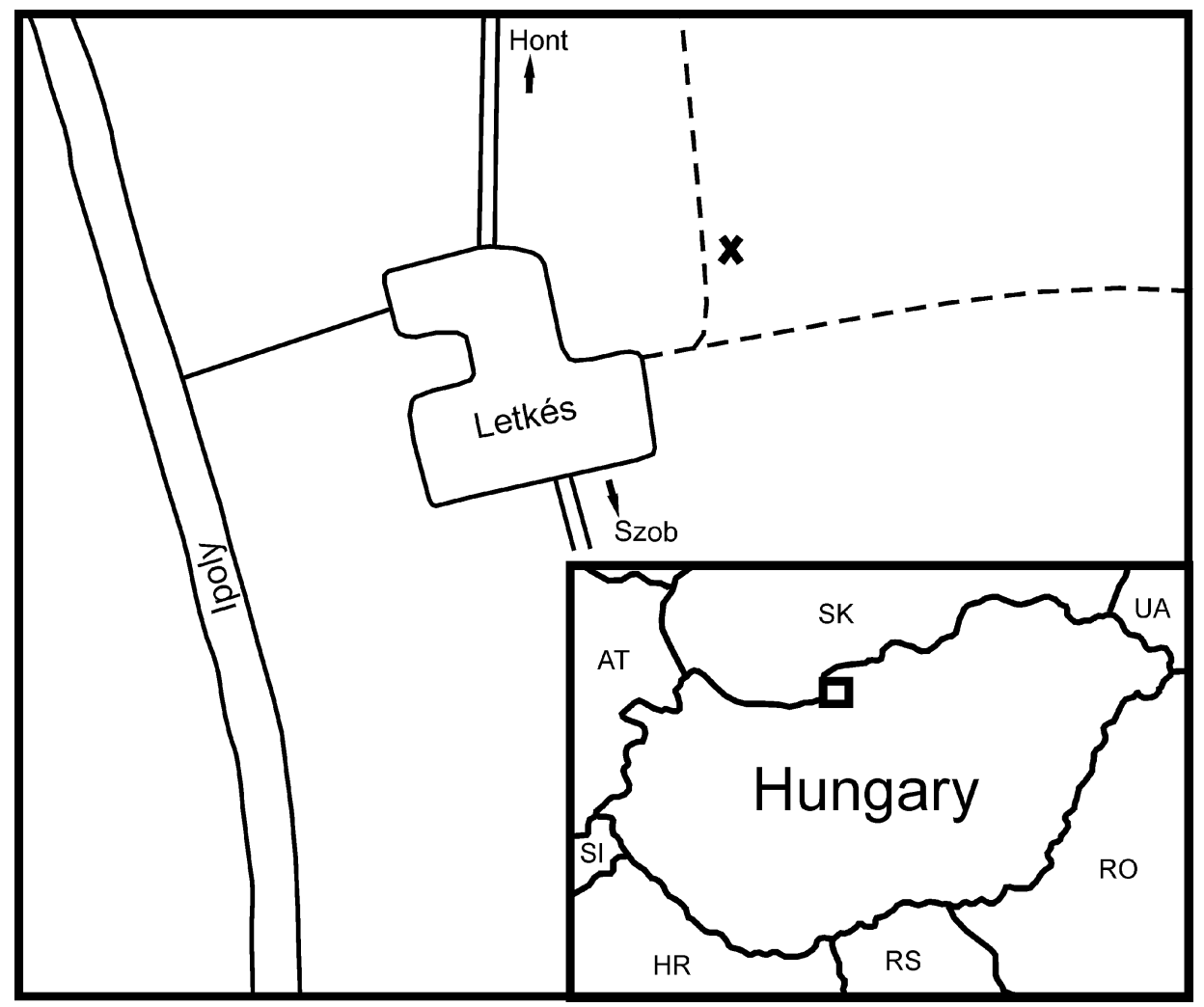

Fig. 1. The lower Badenian locality at Letkés, W Börzsöny Mts, N Hungary 
Hungary), Helmut Krock (Lüneburg, Germany), and Tamás Németh (Balatonkenese, Hungary). The holotype of Semicassis szilviae n. sp. is deposited in the Hungarian Natural History Museum, Department of Palaeontology and Geology, Budapest. In morphological terminology, taxonomy and interpretation of Tonnoidea and Ficoidea taxa we follow LANDAU et al. $(2004,2009,2013)$ and VAN Dingenen $e t$ al. (2016).

Abbreviations used in text: shell length (SL) and maximum width (MD) in mm. NEA $=$ Northeast Atlantic, NSB $=$ North Sea Basin, PMS $=$ ProtoMediterranean Sea, $\mathrm{CP}=$ Central Paratethys, WA $=$ Western Atlantic, Coll. TH = collection $\mathrm{T}$. Hirmetzl, Coll. $\mathrm{HK}=$ collection $\mathrm{H}$. Krock, Coll. $\mathrm{TN}=$ collection T. Németh.

\author{
SYSTEMATIC PALAEONTOLOGY \\ Class Gastropoda Cuvier, 1797 \\ Superorder Caenogastropoda Cox, 1960 \\ Order Neotaenioglossa Haller, 1882 \\ Superfamily Tonnoidea Suter, 1913 \\ Family Tonnidae Suter, 1913 \\ Genus Eudolium Dall, 1889
}

Eudolium subintermedium (d'Orbigny, 1852)

(Figs 2-3)

1852 Cassis subintermedia - D'ORBIGNY, p. 90.

1966 Cassidaria cingulifera Hoernes \& Auinger - STrausz, p. 241, fig. 116.

1969b Cassidaria cingulifera Hoernes et Auinger - Csepreghy-Meznerics, pl. 7, fig. 2.

2009 Eudolium subintermedium (d'Orbigny) - LANDAU et al., p. 63, pl. 1, figs 1-6 (cum syn.). (Figs 2-3).

Material - One fragmentary specimen (SL 20); HNHM: INV 2017.663.

Description - Globose shell, low spire, two convex teleoconch whorls preserved, last whorl shouldered by a slightly nodulose primary cord, constricted at the base, ovate aperture. Spiral sculpture of four narrow primary cords with three fine spiral threads in interspaces on the penultimate whorl, last whorl bears nine primary cords with secondary cords and threads in interspaces.

Remarks - The taxonomic revision of the species was accomplished by LANDAU et al. (2009), Cassidaria cingulifera was considered as a synonym of the $E$. subintermedium. The species is very rare in Hungarian localities. The subadult specimen figured here with weakly nodulose sculpture is closely allied in mor- 
phology to the specimen illustrated by Hoernes \& AUINGER (1884, pl. 17, fig. 17, refigured by LANDAU et al. 2009, pl. 1, fig. 1).

Distribution - Badenian: CP (Austria, Bulgaria, Hungary, Poland, Romania), Langhian: NEA (France), Tortonian: PMS (Italy). For Pliocene range see LANDAU et al. (2009).

\section{Genus Malea Valenciennes, 1832 \\ Malea orbiculata (Brocchi, 1814)}

(Figs 4-5)

1814 Buccinum orbiculatum - BRocchi, p. 647, pl. 15, fig. 22.

1966 Dolium orbiculatum Brocchi - STRAusz, p. 253, fig. 120, pl. 64, fig. 7.

2013 Malea orbiculata (Brocchi) - LANDAU et al., p. 123, pl. 17, fig. 1 (cum syn.).

Material - Ten specimens (SL 20-42); in private collections.

Description - Globose shell, low spire, four convex teleoconch whorls, last whorl constricted at the base. Elongate aperture, denticulate outer lip thickened by labral varix, excavated columella with folds, short and wide siphonal canal, short fasciole. Spiral sculpture of broad, slightly rounded cords (16 on the last whorl), narrow interspaces, axial sculpture of fine growth lines.

Remarks - The species was frequently cited as $M$. denticulata (Deshayes) in the literature. According to the revision of orbiculata (LANDAU et al. 2004), Brocchi's specimen represents a juvenile form, therefore denticulata is a junior synonym. $M$. orbiculata is a rare element of the mollusc assemblage of Letkés.

Distribution - Karpatian: CP (Hungary), Langhian: NEA (France), Badenian: CP (Austria, Hungary, Poland), Serravallian: PMS (Turkey), Tortonian: NEA (Portugal), PMS (Italy). For Pliocene range see LANDAU et al. (2013).

Family Cassidae Latreille, 1825

Subfamily Cassinae Latreille, 1825

Genus Cassis Scopoli, 1777

Cassis postmamillaris Sacco, 1890

(Figs 6-9)

1890 Cassis postmamillaris Sacco - SACCo, p. 16, pl. 1, fig. 11.

2013 Cassis postmamillaris Sacco - LANDAU et al., p. 123, pl. 17, figs 2-4, pl. 79, fig. 8 (cum syn.).

2017 Cassis postmamillaris Sacco - Vicián et al., p. 267, pl. 1, figs 13-14. 
Material - 167 specimens (SL 10-83); HNHM: INV 2017.664. (Figs 6-9), INV 2017.665. (14), 152 specimens in private collections.

Description - Large, helmet-shaped shell, low spire, last whorl more than $90 \%$ of the total height, constricted at base. Elongate aperture, thickened, denticulate outer lip, columella with folds, broad, flattened, thickened parietal callus forming triangular apertural shield, deep, recurved siphonal canal. Spiral sculpture of two or three rows of rounded, slightly pointed tubercles, axial sculpture of weakly developed ribs and growth lines.

Remarks - Although the Oligocene C. mamillaris Grateloup was distinguished from the Miocene C. postmamillaris by SACCO (1890), it was overlooked in the Hungarian literature, and the Miocene species was recorded as C. mamillaris from the N Börzsöny and E Cserhát Mts (Noszky 1925, 1940). C. postmamillaris is relatively abundant in the mollusc assemblage studied here.

Distribution - Langhian: PMS (Italy), Badenian: CP (Austria, Czech Republic, Hungary, Romania, Slovakia), Serravallian: PMS (Greece, Turkey). Tortonian: PMS (Italy).

Genus Galeodea Link, 1807

Galeodea echinophora (Linnaeus, 1758)

(Fig. 10)

1758 Buccinum echinophorum - LiNNAEUs, p. 735.

1969 a Cassidaria echinophora pliotriseriata Sacco - CSEPREghy-MEZnERICs, p. 78, pl. 2, figs 21-22. 2004 Galeodea echinophora (Linnaeus) - LANDAU et al., p. 43, pl. 2, fig. 2 (cum syn.).

2009 Galeodea echinophora (Linnaeus) - LANDAU et al., p. 66, pl. 3, figs 1-2 (cum syn.).

Material - Six specimens (SL 36-48); in private collections.

Description - Fusiform shell, moderately elevated spire, five subangulate teleoconch whorls with slightly concave sutural ramp, convex, expanded last whorl. Ovate aperture, denticulate outer lip thickened by labral varix, wide pseudoumbilicus. Spiral sculpture of fine cords, nodulose shoulder, two rows of nodules on the last whorl, axial sculpture of fine growth lines.

Remarks - The species has a large but fragile shell, so complete shells are very rare in the resedimented layers of the Letkés section.

Distribution - Burdigalian: PMS (Italy), NSB (Germany), Eggenburgian: CP (Germany), late Karpatian: CP (Slovakia), Badenian: CP (Austria, Bulgaria, Hungary, Romania), Tortonian: NEA (Portugal), PMS (Italy). For Pliocene range see VAN DINGENEN et al. (2016). 


\section{Subfamily Phaliinae Beu, 1981 \\ Genus Echinophoria Sacco, 1890 \\ Echinophoria haueri (Hoernes et Auinger, 1884)}

(Fig. 11)

1884 Cassis (b. Cassidea) Haueri - Hoernes \& AuInger, p. 158, pl. 17, fig. 13.

1969 a Cassidaria haueri M. Hörnes - CSEPREghY-MEZneriCs, p. 79, pl. 3, figs 1, 3, 5.

2009 Echinophoria haueri (Hoernes et Auinger) - LANDAU et al., p. 67, pl. 3, figs 6-8, pl. 9, fig. 8 (cum syn.).

Material - 35 specimens (SL 26-38); HNHM: INV 2017.666. (Fig. 11), INV 2017.667. (7), 27 specimens in private collections.

Description - Globose shell, low spire, protoconch of 3.5 smooth, convex whorls, four convex teleoconch whorls, last whorl $90 \%$ of the total height, constricted at the base. Ovate aperture, denticulate outer lip thickened by labral varix, short, deep, recurved siphonal canal, expanded parietal callus, slightly excavated columella with folds. Spiral sculpture of numerous narrow spiral cords, nodulose shoulder, axial sculpture of weak riblets (16-20 on the last whorl).

Remarks - E. haueri is typical of the Paratethys, it clearly differs in morphology from the similar Middle Miocene Mediterranean E. variabilis (Bellardi et Michelotti) in lack of distinct rows of tubercles on the last whorl (LANDAU et al. 2009).

Distribution - Early Miocene: PMS (Italy), Badenian: CP (Austria, Bulgaria, Hungary, Romania).

Genus Cypraecassis Stutchbury, 1837

Cypraecassis cypraeiformis (Borson, 1820)

(Figs 12-13)

1820-1825 Cassis Cypraeiformis - Borson, p. 229, pl. 1, fig. 20.

1966 Cypraecassis crumena cypraeiformis Borson - STRAUSZ, p. 246, pl. 64, figs 10-11.

2013 Cypraecassis cypraeiformis (Borson) - LANDAU et al., p. 124, pl. 17, fig. 5 (cum syn.).

Material - 27 specimens (SL 21-35); HNHM: INV 2017.668. (Figs 12-13), INV 2017.669. (2), 24 specimens in private collections.

Description - Ovate shell, low spire, four teleoconch whorls, slightly convex last whorl more than $80 \%$ of the total height, constricted at the base. Narrow, elongate aperture, denticulate outer lip thickened by labral varix, short, narrow siphonal canal, short, recurved fasciole. Smooth shell with axial sculpture of fine growth lines. 


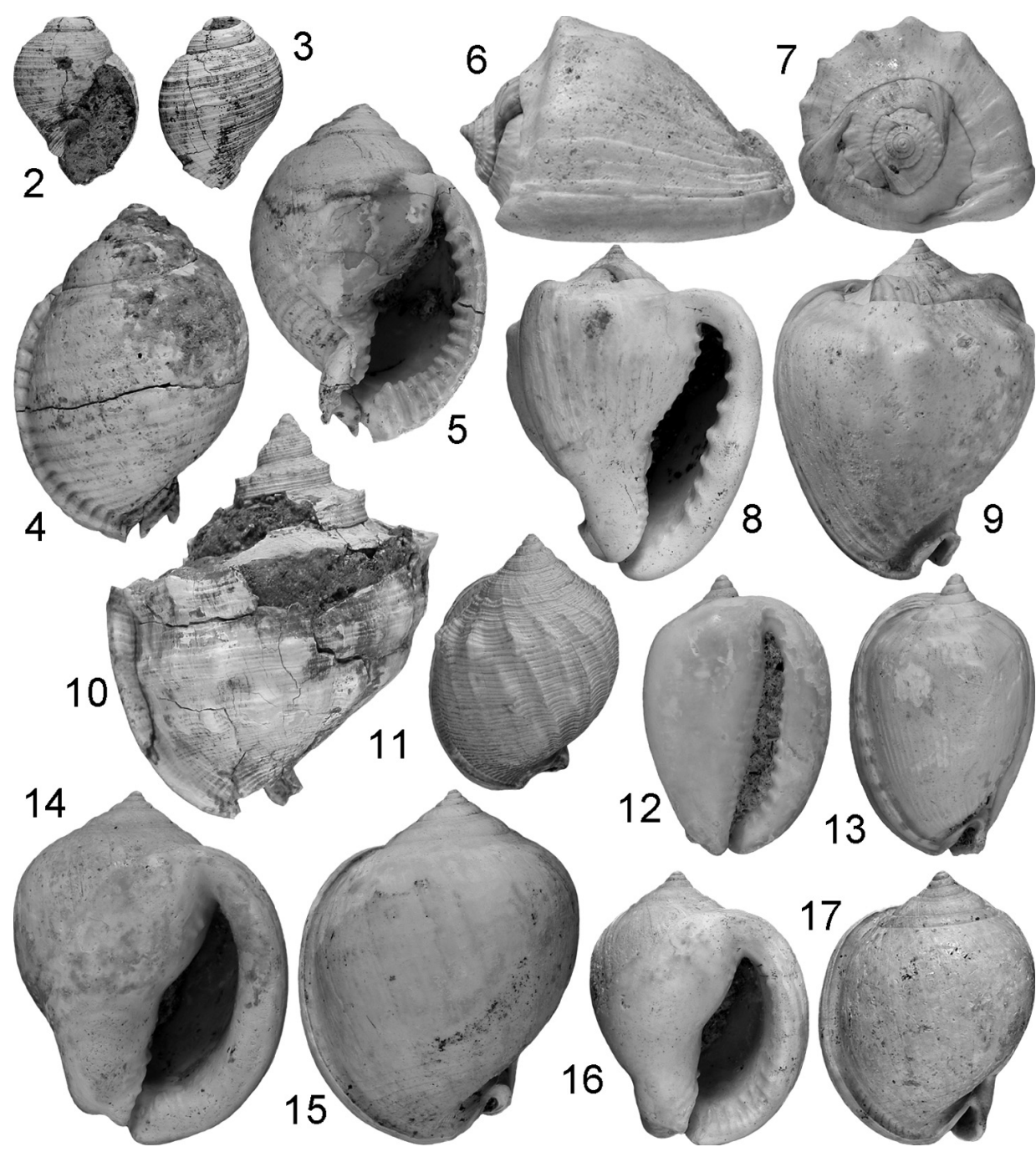

Figs 2-3. Eudolium subintermedium (d'Orbigny), HNHM INV 2017.663., SL 20, MD 14 (1×), apertural and abapertural views. - Figs 4-5. Malea orbiculata (Brocchi), Coll. TH, SL 40, MD $27(1 \times)$, abapertural and apertural views. - Figs 6-9. Cassis postmamillaris Sacco, HNHM INV 2017.664., SL 41, MD 31 (1×), lateral, apical, apertural and abapertural views. - Fig. 10. Galeodea echinophora (Linnaeus), Coll. TH, SL 48, MD $38(1 \times)$, abapertural view. - Fig. 11. Echinophoria haueri (Hoernes et Auinger), HNHM INV 2017.666., SL 31, MD 23, abapertural view. - Figs 1213. Cypraecassis cypraeiformis (Borson), HNHM INV 2017.668., SL 33, MD 22 (1×), apertural and abapertural views. - Figs 14-17. Semicassis laevigata (Defrance). - 14-15. HNHM INV 2017.670., SL 42, MD 34 (1×), apertural and abapertural views. - 16-17. HNHM INV 2017.671., SL 33, MD $26(1 \times)$, apertural and abapertural views 
Remarks - Both the genus and the species was thoroughly discussed by LANDAU et al. (2004). C. cypraeiformis is widespred in the European Middle Miocene to Middle Pliocene, but it is a rare element of the mollusc assemblages.

Distribution - Burdigalian-Langhian: PMS (Italy), Badenian: CP (Austria, Czech Republic, Hungary, Poland, Romania), Serravallian: PMS (Turkey), Tortonian: NEA (Portugal), PMS (Italy). For Pliocene range see LANDAU et al. (2013).

Genus Semicassis Mörch, 1853

Semicassis laevigata (Defrance, 1817)

(Figs 14-17)

1817 Cassis laevigata - Defrance, vol. 7, p. 210.

1966 Phalium (Semicassis) saburon miolaevigatum Sacco - ST RAUSZ, p. 244, pl. 64, fig. 4, pl. 72, figs $15-17$, pl. 73, figs $1-5$.

2013 Semicassis laevigata (Defrance) - LANDAU et al., p. 125, pl. 17, fig. 6 (cum syn.).

Material - 351 specimens (SL 12-44); HNHM: M.62.829-831, INV 2017.670. (Figs 14-15), INV 2017. 671. (Figs 16-17), INV 2017.672 (9), 337 specimens in private collections.

Description - Globose shell, low spire, slightly convex spire whorls, convex, smooth last whorl more than $80 \%$ of the total height, constricted at the base. Wide aperture, outer lip thickened by labral varix, smooth with small denticles, short, deep, recurved siphonal canal, plicate columella, short, recurved fasciole. Spiral sculpture of fine grooves on the spiral whorls, two fine grooves on the concave sutural ramp of the last whorl, axial sculpture of growth lines.

Remarks - S. laevigata is widely distributed in the Badenian localities of Hungary but generally it is a rare element of the mollusc assemblages. Its abundance is noteworthy; it was the most dominant tonnoidean species in the Letkés material.

Distribution - Karpatian: CP (Austria, Czech Republic, Hungary), Burdigalian-Langhian: NSB (the Netherlands, Germany), PMS (Italy), Badenian: CP (Austria, Bosnia, Bulgaria, Czech Republic, Hungary, Poland, Romania, Serbia, Slovenia, Ukraine), Serravallian: NEA (France), PMS (Turkey), Tortonian: NSB (Denmark), NEA (Portugal, S Spain), PMS (Italy). For Pliocene range see VAN Dingenen et al. (2016).

Semicassis szilviae n. sp.

(Figs 18-24)

Holotype - PAL 2017.58.1., Hungarian Natural History Museum, Department of Palaeontology and Geology, (SL 21.5, MD 14.5) (donation of Tamás Hirmetzl) (Figs 21-22). 
Paratypes - 1st: Coll. Z. Vicián (SL 17, MD 11.5) (Figs 23-24), 2nd: Coll. T. Hirmetzl (SL 26, MD 18) (Figs 18-20), 3rd: HNHM PAL 2017.59.1., 4th: PAL 2017.60.1.

Type strata - Lower Badenian (Middle Miocene) clayey sand (Sámsonháza Formation).

Type locality - Letkés, W Börzsöny Mts, N Hungary.

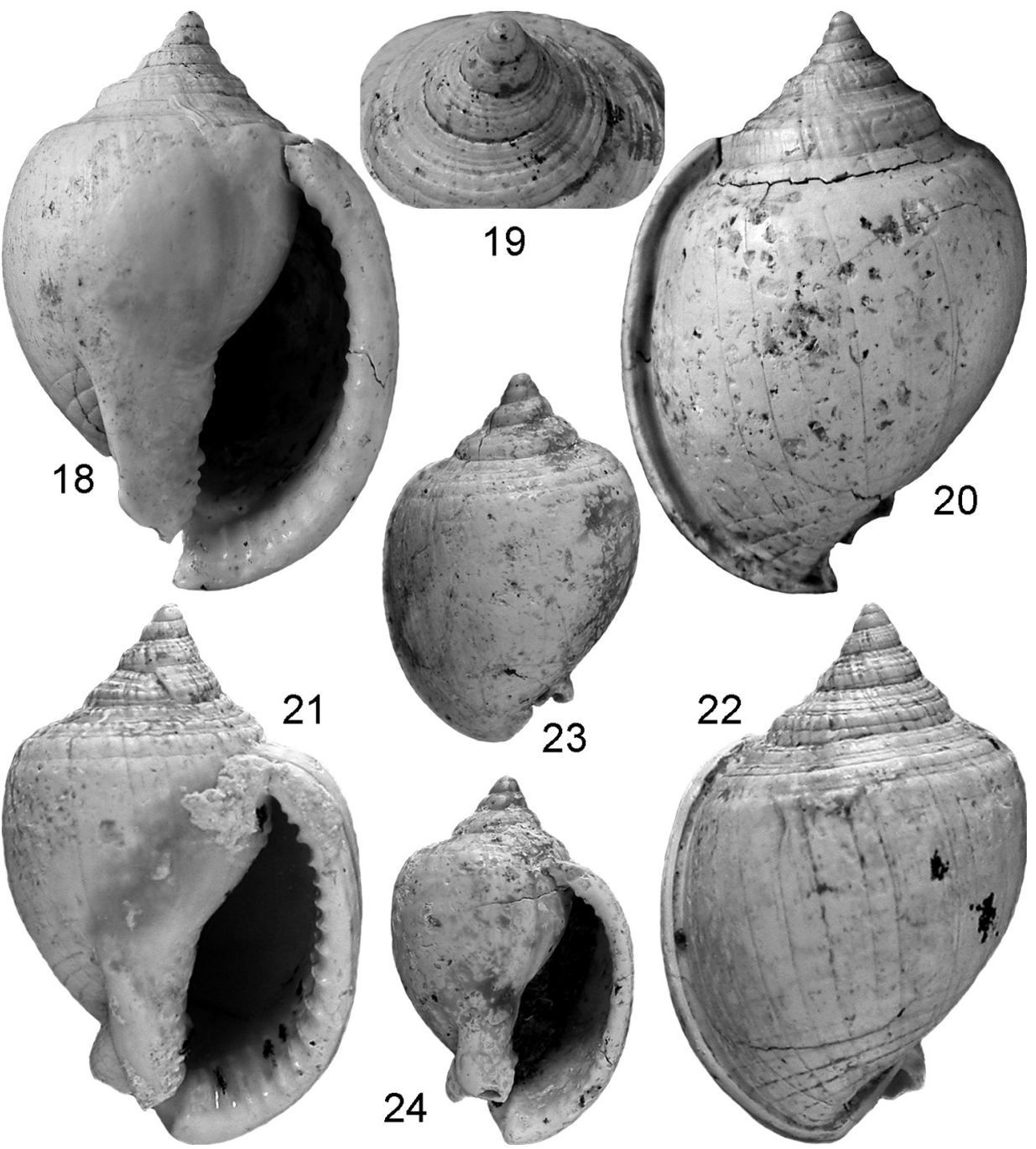

Figs 18-24. Semicassis szilviae n. sp. - 18-20. 2nd paratype, Coll. TH, SL 26, MD 18 (2.6×), apertural, apical and abapertural views. - 21-22. Holotype, HNHM PAL 2017.58.1., SL 21.5, MD 14.5 $(3 \times)$, apertural and abapertural views. - 23-24. 1st paratype, Coll. ZV, SL 17, MD $11.5(2.6 \times)$, abapertural and apertural views 
Derivation of name - In honour of Szilvia Józan (Budapest).

Material - 14 specimens; HNHM: PAL 2017.58.1., 59.1, 60.1., 11 specimens in private collections.

Diagnosis - Subovate shell, moderately elevated spire, multispiral protoconch, convex last whorl, wide aperture, denticulate outer lip, short, recurved siphonal canal, excavated columella with irregular folds, four narrow spiral cords on the ramp, one strong cord at the shoulder, deep, widely spaced grooves on the last whorl, weak varices and growth lines.

Description - Subovate shell (largest specimen: SL $27 \mathrm{~mm}$ ). Moderately elevated spire with concave outline, protoconch of 2.5 convex, smooth whorls, boundary delimited by slightly prosocline scar. Teleoconch of five whorls, subangulate spire whorls with concave sutural ramp. Convex last whorl ( $85 \%$ of the total height) with concave ramp, constricted at the base. Wide aperture, outer lip thickened by labral varix, 17 regular denticles on the inner edge, parietal callus expanded, thin. Short, deep, recurved siphonal canal, broadly excavated columella with irregular folds, short fasciole, abaxially recurved. Spiral sculpture of four narrow cords on the spire ramp and one strong cord at the shoulder, and deep, narrow, widely spaced grooves on the entire last whorl, weakening with ontogeny, axial sculpture of weak varices and growth lines with small tubercles at intersections.

Remarks - Based on overall morphology the new species is assigned to genus Semicassis. It is characterized by intraspecific variability in sculpture: some specimens have almost smooth last whorl. The species differs from $S$. laevigata by smaller and narrower shell, by higher, narrower, step-like spire, by less thickened labral varix, and by sculpture with axial ribs on the spire and regular spiral grooves on the last whorl. It also differs from the Early Miocene S. grateloupi (Deshayes) by narrower shell and spire, and by lack of broad spiral cords on the last whorl. The closest form is the small S. subsulcosa pedemontana Sacco from the Early Miocene of the Torino Hills (see FERrero Mortara et al. 1984, pl. 1, fig. 5); however, it differs by somewhat broader convex shell, thicker labral varix and stronger cords on the last whorl.

Distribution - Badenian: CP (Hungary).

Family Ranellidae J. E. Gray, 1854

Subfamily Ranellinae J. E. Gray, 1854

Genus Ranella Lamarck, 1816

Ranella olearia (Linnaeus, 1758)

(Figs 25-26)

1758 Murex olearium - LinNaEUs, p. 748.

1969 a Bursa (Ranella) gigantea Lam. - CsEPREghY-MEZnERICs, p. 80, pl. 3, figs 13, 16-17.

2009 Ranella olearia (Linnaeus) - LANDAU et al., p. 70, pl. 5, figs 3-4 (cum syn.). 
Material - Four specimens (SL 62-74); in private collections.

Description - Fusiform shell, elevated spire, six convex teleoconch whorls, concave sutural ramp, nodulose shoulder, last whorl constricted at the base. Ovate aperture, denticulate outer lip thickened by labral varix, long, recurved siphonal canal. Spiral sculpture of two primary and numerous secondary cords both on the ramp and below the shoulder on the spire whorls, strong cords and four rows of nodes on the last whorl, axial sculpture of rounded ribs ( 9 on the last whorl), fine growth lines, two varices per whorl.

Remarks - The wide palaeogeographical and stratigraphical ranges, as well as the morphological variability of the species was discussed in detail by LANDAU et al. (2004). $R$. olearia is a rare element of the studied assemblage.

Distribution - Burdigalian-Tortonian: PMS (Italy), Langhian: NEA (France), Badenian: CP (Austria, Czech Republic, Hungary, Poland, Romania). For PlioceneRecent range see LANDAU et al. (2004).

\section{Subfamily Cymatiinae Iredale, 1913 \\ Genus Charonia Gistel, 1848 \\ Charonia lampas (Linnaeus, 1758)}

(Figs 27-28)

1758 Murex lampas - LinNaEus, p. 748.

2004 Charonia lampas (Linnaeus) - LANDAU et al., p. 53, pl. 4, fig. 1 (cum syn.).

2013 Charonia lampas (Linnaeus) - LANDAU et al., p. 126, pl. 18, figs 1-3 (cum syn.).

Material - 28 specimens (SL 20-74); HNHM: INV 2017.673. (Fig. 27), INV 2017.674. (5), 22 specimens in private collections.

Description - Large, fusiform shell, elevated spire, slightly convex teleoconch whorls, concave sutural ramp, last whorl $72 \%$ of the total height, constricted at the base. Ovate aperture, denticulate outer lip thickened by labral varix, short, deep, recurved siphonal canal, excavated, plicate columella, long fasciole. Spiral sculpture of numerous fine cords, two rows of tubercles on spire whorls, two stronger and three weaker rows on the last whorl, axial sculpture of varices.

Remarks - The species is characterized by wide palaeogeographical and stratigraphical distributions, and extreme morphological variability; the taxonomic revision was accomplished by LANDAU et al. (2004). C. lampas was recorded from Sámsonháza (Cserhát Mts) by NoszKY (1925) as Triton nodiferum Lamarck, but it has never been illustrated in the Hungarian literature.

Distribution - Aquitanian-Burdigalian: NEA (France), Burdigalian: PMS (Italy), Badenian: CP (Austria, Hungary, Poland), Serravallian: PMS (Turkey), 
Late Miocene: Caribbean (Dominican Republic), Pacific (Japan, New Zealand). For Eocene and Pliocene-Recent range see LANDAU et al. (2013).
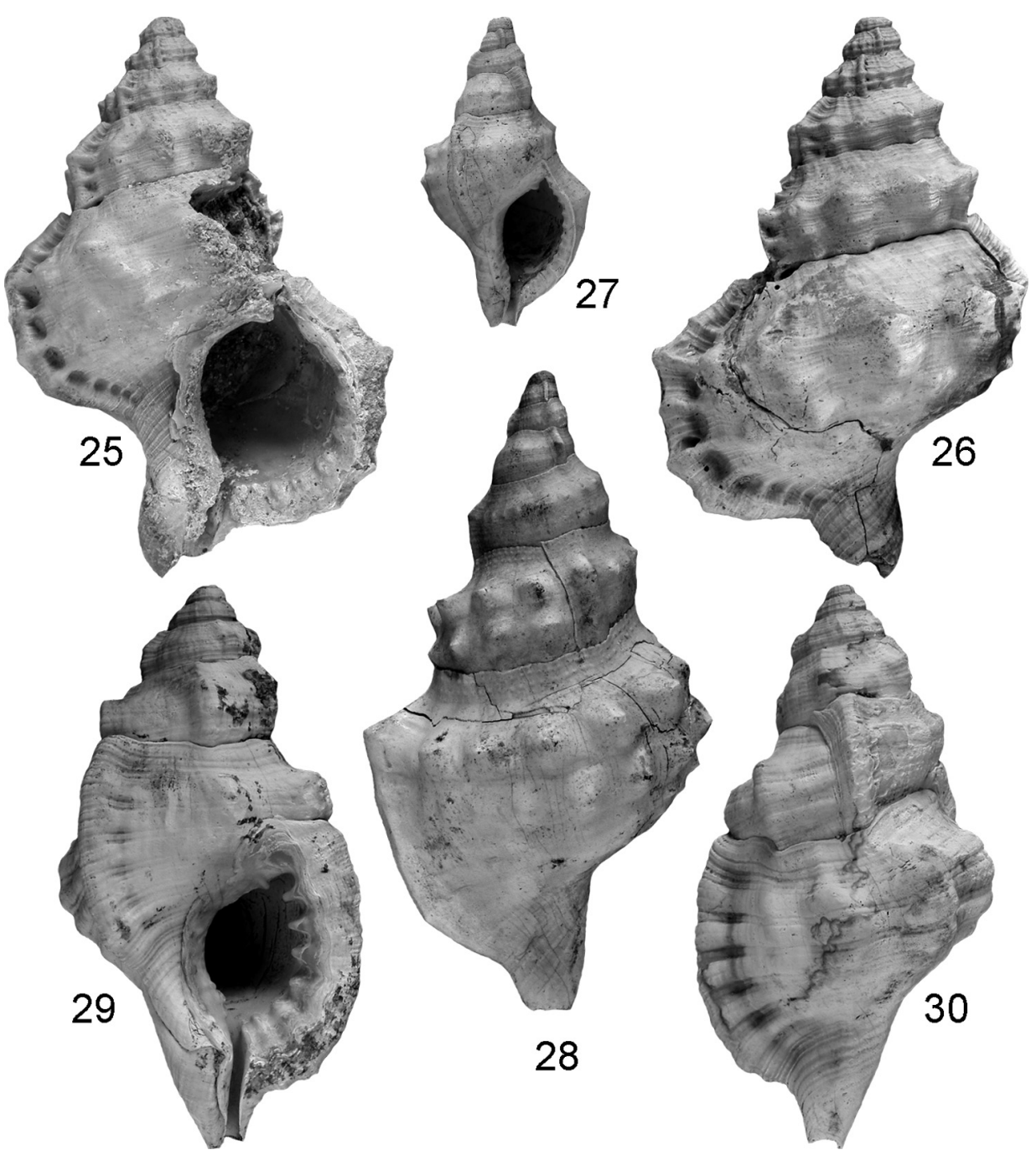

Figs 25-26. Ranella olearia (Linnaeus), Coll. TH, SL 74, MD 50.5 (0.9×), apertural and abapertural views. - Figs 27-28. Charonia lampas (Linnaeus). - 27. HNHM INV 2017.673., SL 36, MD 20 (1×), apertural view. - 28. Coll. TH, SL 76, MD 40 (1×), abapertural view. - Figs 29-30. Monoplex corrugatus (Lamarck), Coll. TH, SL 74, MD $41.5(0.9 \times)$, apertural and abapertural views 
Genus Monoplex Perry, 1810

Monoplex corrugatus (Lamarck, 1816)

(Figs 29-30)

1816 Triton corrugatum - LAMARCK, p. 5.

1966 Cymatium (Lampusia) affine Deshayes - STRAusz, p. 247, pl. 29, figs 8-11, pl. 30, figs 1-5. 2013 Monoplex corrugatus (Lamarck) - LANDAU et al., p. 127, pl. 18, figs 5-7 (cum syn.).

Material - 123 specimens (SL 18-74); HNHM: M.62.836., INV 2017.675. (9), 113 specimens in private collections.

Description - Narrow, fusiform shell, elevated spire, six subangulate teleoconch whorls, broad, concave sutural ramp, last whorl $70 \%$ of the total height. Ovate aperture, denticulate outer lip thickened by labral varix, long, narrow, straight siphonal canal, concave columella with folds, long fasciole. Spiral sculpture of three primary and numerous secondary cords on the spire, six broad primaries on the last whorl, axial sculpture of seven prosocline rounded ribs, one varix per whorl.

Remarks - The species is characterized by large morphological variability, so Triton affine Deshayes - that was frequently recorded from the Mediterranean and the Paratethys - is considered as a junior synonym in the recent literature. $M$. corrugatus is abundant in the mollusc assemblage of Letkés.

Distribution - Burdigalian: PMS (Italy), late Burdigalian-Langhian: NSB (the Netherlands), Badenian: CP (Austria, Bulgaria, Czech Republic, Hungary, Poland, Romania, Ukraine), Serravallian: PMS (Turkey), Tortonian: NEA (Portugal), PMS (Italy). For Pliocene-Recent range see LANDAU et al. (2013).

Monoplex subcorrugatus (d'Orbigny, 1852)

(Figs 31-32)

1852 Triton subcorrugatum - D'ORBIGNY, p. 77.

1969 a Cymatium (Ranularia) multicostatum Cossmann et Peyrot - Csepreghy-Meznerics, p. 80, pl. 3, figs 9-12.

2001 Cymatium subcorrugatum (d'Orbigny) - Lozouet et al., p. 46, pl. 19, fig. 1 (cum syn.). 2009 Monoplex subcorrugatus (d'Orbigny) - LANDAU et al., p. 71 (pars).

Material - Three specimens (SL 20-26); HNHM: INV 2017.676. (2), one specimen in private collection.

Description - Broad shell, elevated spire, four subangulate teleoconch whorls, slightly concave, sloping sutural ramp, convex last whorl. Ovate aperture, denticulate outer lip thickened by labral varix, weakly plicate columella. Spiral sculpture of fine cords on the ramp, two well-developed primary cords on the spire whorls and 6 on the last whorl (adapical five divided by median grooves), 
one secondary cord in interspaces, axial sculpture of broad, rounded ribs (7-9 on the last whorl) and growth lines.

Remarks - M. subcorrugatus differs in morphology from $M$. corrugatus in smaller size, broader shell and lack of varices on the early teleoconch whorls, it is probably the ancestor of the latter. It also differs from $M$. heptagonus in broader shell, conical spire and less developed, broader primary cords.

Distribution - Aquitanian-Langhian: NEA (France), late Burdigalian-Langhian: NSB (the Netherlands), Badenian: CP (Hungary).

Monoplex heptagonus (Brocchi, 1814)

(Figs 33-34)

1814 Murex heptagonus - Brocchi, p. 404, pl. 9, fig. 2.

1966 Cymatium (Ranularia) heptagonum vindobonicum Cossmann \& Peyrot - STraUsz, p. 248, pl. 29, fig. 7.

2013 Monoplex heptagonus (Brocchi) - LANDAU et al., p. 128, pl. 18, figs 8-10 (cum syn.).

Material - 106 specimens (SL 10-25); HNHM: M.62.835., INV 2017.677. (Figs 33-34), INV 2017.678. (7), 97 specimens in private collections.

Description - Small shell, moderately elevated, step-like spire, four, convex, shouldered teleoconch whorls, slightly convex, subtrigonal last whorl with sloping sutural ramp. Ovate aperture, denticulate outer lip thickened by labral varix, long, narrow, straight siphonal canal, plicate columella, thickened parietal callus, long fasciole. Spiral sculpture of three well-developed primary cords on the spire whorls and 5-6 on the last whorl, one secondary cord in interspaces, axial sculpture of broad, rounded ribs (7-8 on the last whorl), growth lines and one varix on the last whorl, tubercles at intersections.

Remarks - The morphology of the species is very similar to that of $M$. corrugatus (see BA£UK 1995), but it differs in scalate spire, more strongly shouldered whorls and more raised spiral cords. The $M$. heptagonus material of Letkés shows moderate intraspecific variability in development of sculpture. The species was abundant in the mollusc assemblage.

Distribution - Burdigalian: PMS (Italy), Badenian: CP (Austria, Bulgaria, Hungary, Poland, Romania), Serravallian: PMS (Turkey), Tortonian: PMS (Italy). For Pliocene range see VAN Dingenen et al. (2016).

Monoplex sp.

(Figs 35-36)

Material - One adult specimen (SL 30.5); in private collection.

Description - Squat, subovate shell, moderately elevated, conical spire, protoconch missing, four, convex, shouldered teleoconch whorls with concave sutural 
ramp, convex last whorl. Ovate aperture, outer lip thickened by labral varix, six denticles within, long, narrow, slightly curved siphonal canal, plicate columella, thickened parietal callus. Spiral sculpture of four narrow cords on the ramp and six cords on the penultimate whorl, and eight primary cords (five adapical divided by median grooves) on the last whorl, secondary cords in interspaces, axial sculpture of broad, rounded ribs (7 on the last whorl), fine growth lines and one varix on the last whorl.
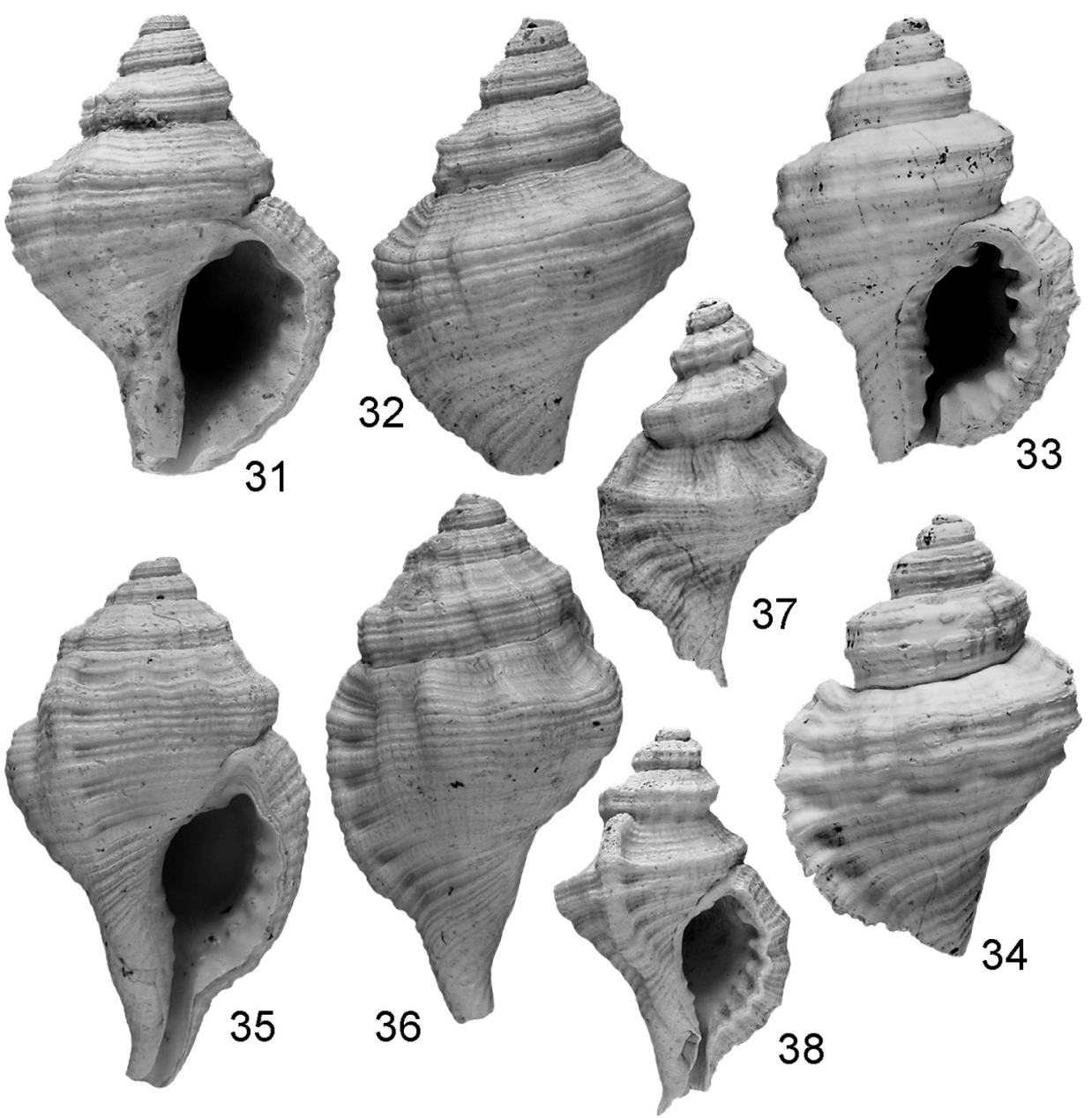

Figs 31-32. Monoplex subcorrugatus (d'Orbigny), Coll. TN, SL 26, MD 18 (2×), apertural and abapertural views. - Figs 33-34. Monoplex heptagonus (Brocchi), HNHM INV 2017.677., SL 25, MD $17(2 \times)$, apertural and abapertural views. - Figs 35-36. Monoplex sp., Coll. TH, SL 30.5, MD $18(2 \times)$, apertural and abapertural views. - Figs 37-38. Turritriton grundensis (Hoernes et Auinger), HNHM INV 2017.679., SL 22, MD 12 (2×), abapertural and apertural views 
Remarks - The morphology differs from that of both $M$. heptagonus and M. subcorrugatus in broader and conical spire, narrower aperture and much finer spiral cords. The specimen probably represents a new species.

Distribution - Badenian: CP (Letkés, Hungary).

Genus Turritriton Dall, 1904

Turritriton grundensis (Hoernes et Auinger, 1884)

(Figs 37-38)

1884 Triton (d. Simpulum) Grundense - Hoernes \& Auinger, p. 177, pl. 21, fig. 16.

2009 Turritriton grundensis (Hoernes \& Auinger) - LANDAU et al., p. 72, pl. 6, fig. 5 (cum syn.).

Material - 13 specimens (SL 17-22); HNHM: INV 2017.679. (Figs 37-38), 12 specimens in private collections.

Description - Gracile shell, high, step-like spire, spire whorls with two strong spiral cords at mid-whorl, sloping ramp, strongly shouldered last whorl. Ovate aperture, denticulate outer lip thickened by labral varix, long, narrow, straight siphonal canal, columella with two folds, thickened parietal callus. Spiral sculpture of well-developed primary and secondary cords, axial sculpture of broad, rounded ribs, growth lines and one varix on the last whorl.

Remarks - The species is typical of the Central Paratethys. It differs in morphology from the similar M. heptagonus in slender shell, sloping sutural ramp and finely reticulate surface. T. grundensis is a new record in Hungary.

Distribution - Badenian: CP (Austria, Hungary, Poland).

Genus Sassia Bellardi, 1873

Sassia apenninica (Sassi, 1827)

(Figs 39-40, 45)

1827 Triton apenninicum - SASsI, p. 480.

1956 Charonia (Sassia) apenninica Sassi - Csepreghy-Meznerics, p. 397, pl. 4, figs 13-14.

2013 Sassia apenninica (Sassi) - LANDAU et al., p. 130, pl. 19, fig. 4.

Material - Ten specimens (SL 13-29); HNHM: M.62.831-834., INV 2017.680. (3), three specimens in private collections.

Description - Fusiform shell, elevated spire, carinate teleoconch whorls, steep sutural ramp, rounded last whorl. Ovate aperture, denticulate outer lip thickened by labral varix, long, narrow, recurved siphonal canal, plicate columella. Spiral sculpture of strong primary and narrow secondary cords, axial sculpture of riblets, one varix per whorl. 
Remarks - The taxonomy and the morphological variability of $S$. apenninica were discussed in detail by LANDAU et al. (2004). As the species is typical of the deeper-water deposits, it is rare in the shallow-water marly sand dominated Letkés section.

Distribution - Aquitanian-Langhian: NEA (France), Burdigalian: PMS (Italy), Badenian: CP (Austria, Bulgaria, Czech Republic, Hungary, Poland, Romania), Serravallian: PMS (Turkey), Tortonian: PMS (Italy). For Pliocene range see LANDAU et al. (2013).

Sassia turrita (Eichwald, 1830)

(Figs 41-42)

1830 Tritonium turritum - EICHWALD, p. 225.

1966 Charonia (Sassia) tarbelliana Grateloup - STRAUSz, p. 249, pl. 30, figs 7-8.

2013 Sassia turrita (Eichwald) - LANDAU et al., p. 130, pl. 19, figs 5-8, pl. 62, fig. 9 (cum syn.).

Material - 43 specimens (SL 15-48); HNHM: INV 2017.681. (Figs 41-42), INV 2017.682. (5), 37 specimens in private collections.

Description - Fusiform shell, elevated spire, seven convex teleoconch whorls, shouldered early spire whorls with steep sutural ramp, rounded last whorl, constricted at the base. Ovate aperture, denticulate outer lip thickened by labral varix, long, narrow siphonal canal, long fasciole. Spiral sculpture of narrow cords on the spire, fine threads on the last whorl, axial sculpture of rounded ribs and one or two broad, rounded varices per whorl.

Remarks - The nomenclature problem of the species, the priority of Eichwald's taxon and the replacement of Triton tarbellianum Grateloup was analyzed by LANDAU et al. (2009).

Distribution - Chattian: NSB (Germany), Egerian: CP (Hungary), late Burdigalian-Langhian: NSB (the Netherlands, Belgium, Germany), Langhian-Serravallian: NEA (France), Badenian: CP (Austria, Bulgaria, Czech Republic, Hungary, Poland, Romania, Serbia, Slovakia, Ukraine), Serravallian: PMS (Turkey).

Genus Cymatiella Iredale, 1924

Cymatiella tritonea (Grateloup, 1847)

(Figs 43-44)

1847 Murex tritoneum - GRATELOUP, pl. 29, fig. 23.

1966 Charonia (Sassia) parvula Michelotti - STRAusz, p. 250, pl. 30, fig. 9.

2009 Cymatiella tritonea (Grateloup) - LANDAu et al., p. 74, pl. 7, figs 4-9, pl. 10, fig. 3 (cum syn.).

Material - 21 specimens (SL 11-13); HNHM: INV 2017.683. (5), 16 specimens in private collections. 
Description - Small, fusiform shell, elevated spire, teleoconch of five convex whorls, rounded last whorl, constricted at the base. Small, ovate aperture, denticulate outer lip thickened by labral varix, short siphonal canal and fasciole,
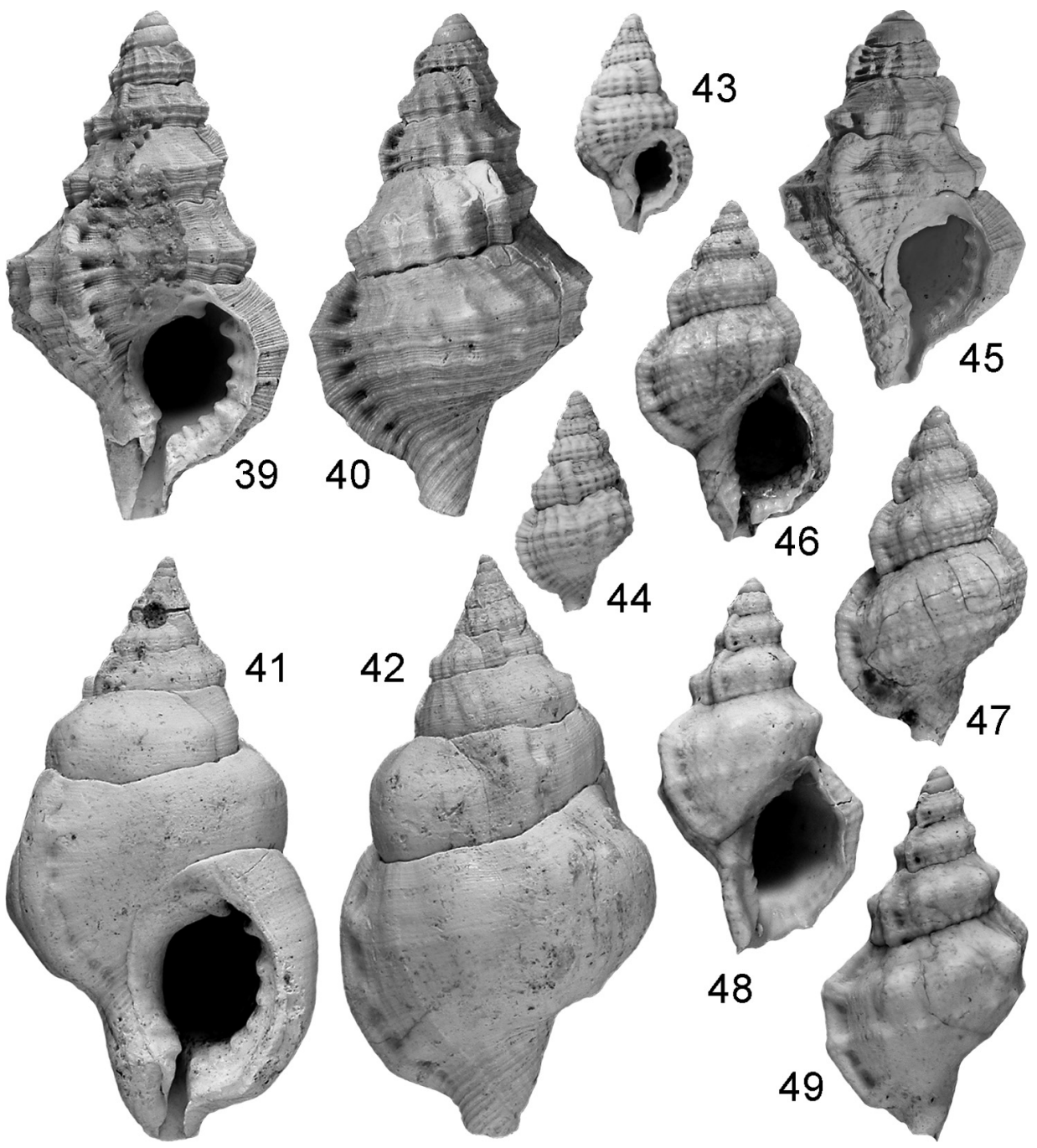

Figs 39-40. Sassia apenninica (Sassi), Coll. TN, SL 29, MD $16(2 \times)$, apertural and abapertural views. - Figs 41-42. Sassia turrita (Eichwald), HNHM INV 2017.681., SL 41, MD 23 (1.5×), apertural and abapertural views. - Figs 43-44. Cymatiella tritonea (Grateloup), Coll. TH, SL 13, MD 7 (2×), apertural and abapertural views. - Fig. 45. Sassia apenninica (Sassi), Coll. HK, SL 15.1, MD 9.8 (3×), apertural view. - Figs 46-47. Bursa scrobilator (Linnaeus), HNHM INV 2017.684. (donation of T. Németh), SL 20, MD 11 (2x), apertural and abapertural views. - Figs 48-49. Bursa ranelloides (Reeve), Coll. TH, SL 22.5, MD $12.5(2 \times)$, apertural and abapertural views 
columella with three folds. Spiral sculpture of cords, axial sculpture of rounded ribs with tubercles at the intersections, one or two varices per whorl.

Remarks - Early Miocene specimens from France and the Paratethys were revised by LANDAU et al. (2004, 2009), and Triton parvulum Michelotti, which had been frequently recorded from the Paratethys was regarded as a synonym of C. tritonea.

Distribution - Chattian-Burdigalian: NEA (France), Burdigalian: PMS (Italy), Karpatian: CP (Austria), Badenian: CP (Austria, Bulgaria, Hungary, Poland, Romania, Serbia), Tortonian: PMS (Italy).

\section{Family Bursidae Thiele, 1925}

Genus Bursa Röding, 1798

Bursa scrobilator (Linnaeus, 1758)

(Figs 46-47)

1758 Murex scrobilator - LinNaEus, p. 749.

1969 a Bursa (Ranella) nodosa subnodosa Sacco - Csepreghy-Meznerics, p. 81, pl. 3, figs 6, 8. 2009 Bursa scrobilator (Linnaeus) - LANDAU et al., p. 75, pl. 7, figs 10-11 (cum syn.).

Material - Three specimens (SL 18-22); HNHM: INV 2017.684. (Figs 4647), two specimens in private collections.

Description - Fusiform shell, elevated spire, protoconch of three smooth, convex whorls, four subangulate teleoconch whorls, convex last whorl $70 \%$ of the total height, constricted at the base. Ovate aperture, convex, denticulate outer lip thickened by labral varix, short anal canal, short, slightly recurved siphonal canal, slightly concave, plicate columella. Spiral sculpture of narrow cords, three fine nodular rows on the sutural ramp, nodulose shoulder, two fine primary nodular rows below shoulder on the last whorl, axial sculpture of two prominent varices per whorl.

Remarks - The high diversity of genus Bursa in the studied assemblage is remarkable: all three species known from the Paratethys occur at Letkés. The specimen figured here represents the "nodosa" form which was typical of the Miocene Paratethys.

Distribution - Badenian: CP (Austria, Hungary, Poland), Tortonian: PMS (Italy), NEA (France). For Pliocene-Pleistocene range of the "nodosa" form see LANDAU et al. (2004).

Bursa ranelloides (Reeve, 1844)

(Figs 48-49)

1844 Triton Ranelloides - ReEve, pl. 3, fig. 10.

2009 Bursa ranelloides (Reeve) - LANDAU et al., p. 75, pl. 8, figs 1-6, pl. 10, fig. 4 (cum syn.). 
Material - Nine specimens (SL 18-23); in private collections.

Description - Fusiform shell, elevated spire, protoconch of three smooth, convex whorls, four subangulate teleoconch whorls, last whorl $74 \%$ of the total height, constricted at the base. Ovate aperture, denticulate, angulate outer lip thickened by labral varix, short anal canal, short, slightly recurved siphonal canal, straight, plicate columella. Spiral sculpture of narrow cords, nodulose shoulder, one row of small tubercles above abapical suture on the spire, three rows of tubercles on the last whorl, axial sculpture of two varices per whorl.

Remarks - The species differs in morphology from $B$. scrobilator by subangulate whorls with stronger sculpture, and from $B$. corrugata by narrower shell with sharper tubercles. B. ranelloides is a new record in Hungary.

Distribution - Burdigalian: PMS (Italy), Badenian: CP (Austria, Hungary, Romania), Middle Miocene: WA (Trinidad). For Pliocene-Recent range see LANDAU et al. (2009).

\section{Bursa corrugata (Perry, 1811)}

(Figs 50-54)

1811 Biplex corrugata - PERRY, pl. 5, fig. 1.

2009 Bursa corrugata (Perry) - LANDAU et al., p. 77, pl. 8, figs 7-10, pl. 10, fig. 5 (cum syn.).

Material - 87 specimens (SL 10.5-28); HNHM: INV 2017.685. (Figs 5253), INV 2017.686. (9), 77 specimens in private collections.

Description - Fusiform shell, elevated spire, protoconch of three smooth, convex whorls, four teleoconch whorls, angulate last whorl $78 \%$ of the total height, constricted at the base. Ovate aperture, denticulate outer lip thickened by labral varix, short, deep anal canal, short, recurved siphonal canal, straight, plicate columella, thickened columellar callus, short fasciole. Papillate surface, spiral sculpture of narrow cords, two rows of tubercles on the spire, four rows on the last whorl (strong tubercles of adapical row -9 on the last whorl - form the shoulder), axial sculpture of two varices per whorl.

Remarks - Based on the revision of fossil and recent bursids, Bursa papillosa (Pusch) frequently recorded from the Paratethys was regarded as a junior synonym of $B$. corrugata by LANDAU et al. (2009). The species shows slight variability in the development of nodes. It is a new record in Hungary.

Distribution - Burdigalian: NEA (France), PMS (Italy), Badenian: CP (Austria, Bulgaria, Hungary, Poland, Romania), Middle Miocene: WA (Trinidad). For Pliocene-Recent range see LANDAU et al. (2009). 
Genus Aspa H. et A. Adams, 1853

Aspa marginata (Gmelin, 1791)

(Figs 55-56)

1791 Buccinum marginatum - GMELIN, p. 3486.

1966 Bursa (Aspa) marginata depressa Grateloup - STRAusz, p. 251, pl. 29, figs 5-6, pl. 63, figs $14-18$.

2013 Aspa marginata (Gmelin) - LANDAU et al., p. 131, pl. 19, fig. 9 (cum syn.).

Material - 160 specimens (SL 14-42); HNHM: INV 2017.687. (Fig. 55), INV 2017.688. (Fig. 56), INV 2017.689. (15), 143 specimens in private collections.

Description - Ovate, dorsoventrally compressed shell, low spire, four teleoconch whorls, convex last whorl $85 \%$ of the total height. Ovate, denticulate aperture, straight, long anal canal, short, recurved siphonal canal, concave columella, thickened parietal callus, short, recurved fasciole. Spiral sculpture of fine cords, tubercles at the shoulder, axial sculpture of two varices per whorl.

Remarks - The species is widely distributed in the Badenian localities of Hungary, and it was abundant in the mollusc assemblage of Letkés.

Distribution - Burdigalian-Langhian: PMS (Italy), Ottnangian: CP (Germany), Karpatian: CP (Austria), Badenian: CP (Austria, Bosnia, Bulgaria, Hungary, Poland, Romania, Ukraine), Serravallian: PMS (Turkey), Tortonian: NEA (Portugal, France), PMS (Italy). For Pliocene-Pleistocene range see LANDAU et al. (2013).

Family Personidae Gray, 1854

Genus Distorsio Röding, 1798

Distorsio cancellina (Lamarck, 1803)

(Figs 57-58)

1803 Murex cancellinus - LAMARCK, p. 225.

2004 Distorsio cancellina (Lamarck) - LANDAu et al., p. 71, pl. 6, figs 1-3 (cum syn.).

2013 Distorsio cancellina (Lamarck) - LANDAU et al., p. 132, pl. 19, figs 10-12 (cum syn.).

Material - 103 specimens (SL 14-43); HNHM: INV 2017.690. (Figs 5758), INV 2017.691. (4), 98 specimens in private collections.

Description - Fusiform shell, moderately elevated, irregularly coiled spire, six teleoconch whorls, last whorl expanded to left of the aperture. Denticulate aperture, short, recurved siphonal canal, short fasciole. Spiral sculpture of narrow cords, axial sculpture of rounded ribs and low varices with small tubercles at the intersections. 
Remarks - The revision of the taxon was accomplished by LANDAU et al. (2004). In Hungary the species was recorded from the Börzsöny and Cserhát Mts as Triton tortuosum Borson (NoszKY 1925), but it has never been illustrated

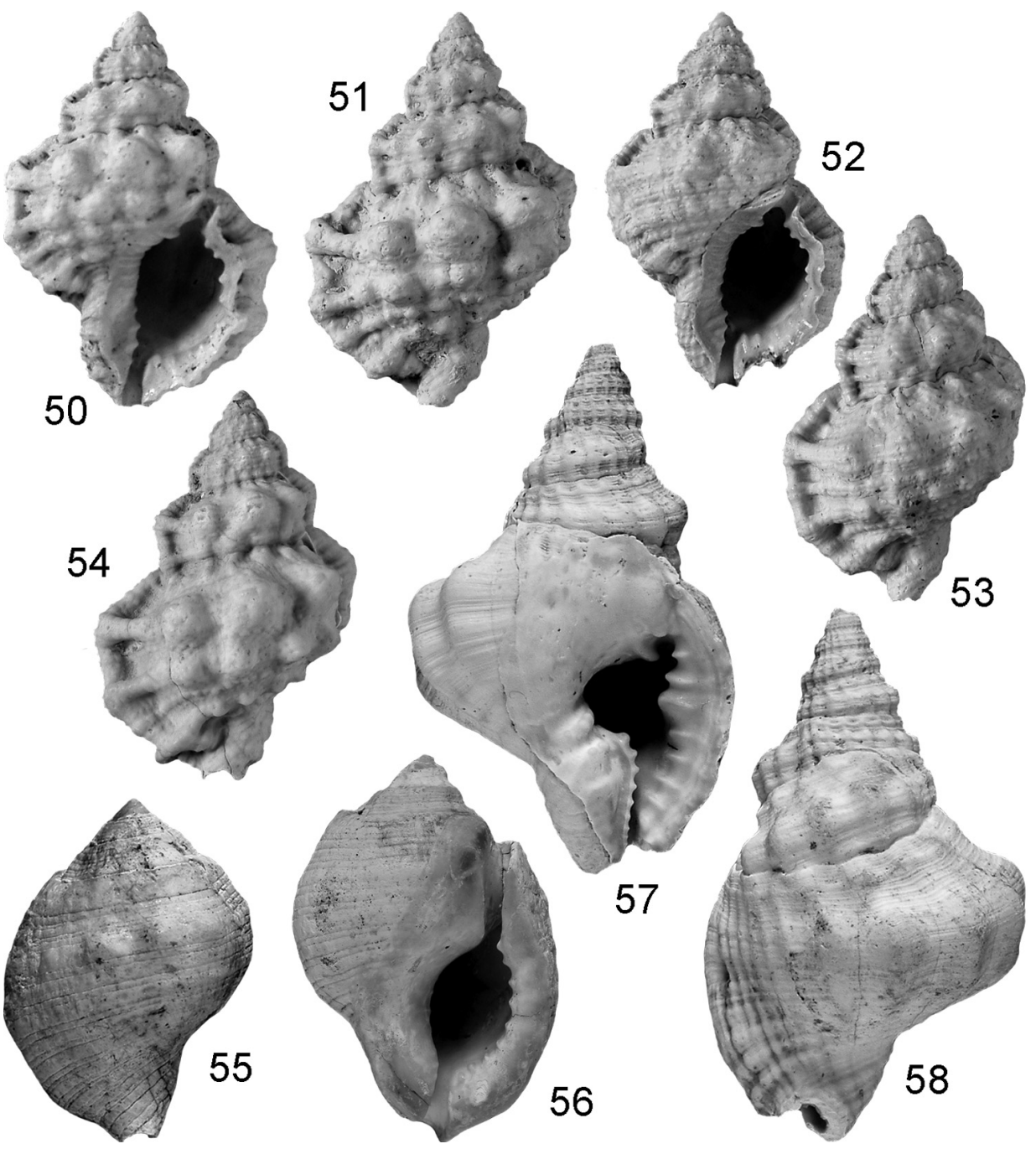

Figs 50-54. Bursa corrugata (Perry). - 50-51. Coll. TH, SL 23.5, MD $15.5(2 \times)$, apertural and abapertural views. - 52-53. HNHM INV 2017.685., SL 23.5, MD $15(2 \times)$, apertural and abapertural views. - 54. Coll. TH, SL 24, MD $16(2 \times)$, abapertural view. - Figs 55-56. Aspa marginata (Gmelin). - 55. HNHM INV 2017.687., SL 33, MD 24 (1.2×), abapertural view. - 56. HNHM INV 2017.688., SL 38, MD 26 (1.2×), apertural view. - Figs 57-58. Distorsio cancellina (Lamarck),

HNHM INV 2017.690., SL 41, MD 26 (1.5×), apertural and abapertural views 
in the Hungarian literature. D. cancellina is rare at the Paratethys localities; its abundance in the mollusc assemblage of Letkés is noteworthy.

Distribution - Burdigalian-Tortonian: PMS (Italy), late Burdigalian-Langhian: NSB (the Netherlands, Germany), Aquitanian-Serravallian: NEA (France), Badenian: CP (Austria, Bulgaria, Hungary, Romania), Langhian-Serravallian: PMS (Turkey), Tortonian: NEA (Portugal). For Pliocene range see LANDAu et al. (2013).

Genus Personopsis Beu, 1988

Personopsis grasi (Bellardi in d'Ancona, 1872)

(Fig. 59)

1872 Triton Grasi Bellardi - D'AnconA, p. 70.

2009 Personopsis grasi (d'Ancona) - LANDAU et al., p. 79, pl. 9, figs 5-7.

Material - One fragmentary specimen (SL 20); in private collection.

Description - Fusiform shell, elevated spire, six weakly convex teleoconch whorls, regularly convex last whorl. Subtrigonal aperture, denticulate outer lip thickened by labral varix, strongly excavated columella, thick parietal callus. Spiral sculpture of three narrow cords on the spiral whorls and 11 on the last whorl, fine threads, axial sculpture of about 16 rounded ribs, one weak varix per whorl.

Remarks - The Paratethys specimens differ in morphology from their Pliocene descendants in Italy by smaller and narrower shell with finer ornamentation. The species is very rare in the Paratethys. P. grasi is a new record in Hungary. Distribution - Badenian: CP (Austria, Hungary, Romania), Tortonian: PMS (Italy). For Pliocene-Recent range see LANDAU et al. (2004).

$$
\begin{gathered}
\text { Superfamily Ficoidea Meek, } 1864 \\
\text { Family Ficidae Meek, } 1864 \\
\text { Genus Ficus } \text { Röding, } 1798
\end{gathered}
$$

Ficus burdigalensis (Sowerby, 1824)

$$
\text { (Figs 60-61) }
$$

1824 Pyrula Burdigalensis - SOWERBY, fig. 2.

1966 Pirula (Fulguroficus) burdigalensis Sowerby - Strausz, p. 256, fig. 121.

2007 Ficus burdigalensis (Sowerby) - PFISTER \& Wegmüller, p. 153, pl. 1, figs 10-15 (cum syn.).

Material - Six specimens (SL 32-38); in private collections.

Description - Ficiform shell, moderately low spire, eroded protoconch, three shouldered teleoconch whorls, last whorl $92 \%$ of the total height. Long aperture, smooth outer lip, long siphonal canal. Spiral sculpture of numerous strong, nar- 
row cords, two rows of spines on the spire, four rows of spines on the last whorl, axial sculpture of fine growth lines.

Remarks $-F$. burdigalensis differs in morphology from its Badenian congeners in characteristic rows of spines on the teleoconch whorls. The species is typical of the Early Miocene, its occurrence in the early Badenian is noteworthy.

Distribution - Aquitanian: NEA (France), Burdigalian: NEA (Portugal), Paratethys (Switzerland), Eggenburgian-Karpatian: CP (Austria, Hungary), Badenian: CP (Hungary).

Ficus condita (Brongniart, 1823)

(Figs 62-64)

1823 Pyrula condita - Brongniart, p. 75, pl. 6, fig. 4.

1966 Pirula condita Brongniart - STraUsz, p. 254, pl. 57, figs 4-6.

2013 Ficus condita (Brongniart) - LANDAU et al., p. 132, pl. 19, fig. 13, pl. 62, fig. 10 (cum syn.).

2016 Ficus condita (Brongniart) - STEIN et al., p. 41, pl. 15, fig. 7.

Material - 32 specimens (SL 21-44); HNHM: INV 2017.692. (Fig. 63), INV 2017.693. (9), 22 specimens in private collections.

Description - Ficiform shell, low spire, protoconch of two convex, smooth whorls, convex teleoconch whorls, last whorl 94-97\% of total height, constricted at base. Long, wide aperture, smooth outer lip, long, slightly recurved siphonal canal. Cancellate sculpture with numerous narrow and strong primary spiral cords and fine secondaries in the interspaces, and fine axial ribs.

Remarks - The morphology of the species differs from that of $F$. cingulata in higher spire and finer sculpture, and from F. geometra in stronger primary cords. It is widely distributed in the Early-Middle Miocene localities of Hungary, and it was the most abundant Ficus species in the mollusc assemblage of Letkés.

Distribution - Aquitanian-Serravallian: NEA (France), Burdigalian: PMS (Italy), Eggenburgian: CP (Austria, Hungary, Slovakia, Romania), Karpatian: CP (Hungary), late Burdigalian-Langhian: NSB (the Netherlands, Belgium, Germany, Denmark), Badenian: CP (Austria, Bulgaria, Hungary, Poland, Romania, Slovakia, Ukraine), Serravallian: PMS (Turkey), Tortonian: PMS (Italy). For Oligocene range see LANDAU et al. (2013).

\section{Ficus geometra (Borson, 1825)}

(Figs 65-66)

1820-1825 Pyrula geometra - Borson, p. 311.

1966 Pirula geometra Borson - STRAUsz, p. 255, pl. 57, figs 1-3.

1973 Pirula geometra Borson - BoRzA, pl. 2, fig. 9.

2004 Ficus geometra (Borson) - LANDAU et al., p. 79, pl. 8, fig. 3 (cum syn.).

2007 Ficus geometra (Borson) - PFISTER \& WEgMüLler, p. 155, pl. 1, figs 21-23, pl. 2, figs 1-4. 
Material - Seven specimens (SL 26-31); HNHM: INV.2017.695., six specimens in private collections.
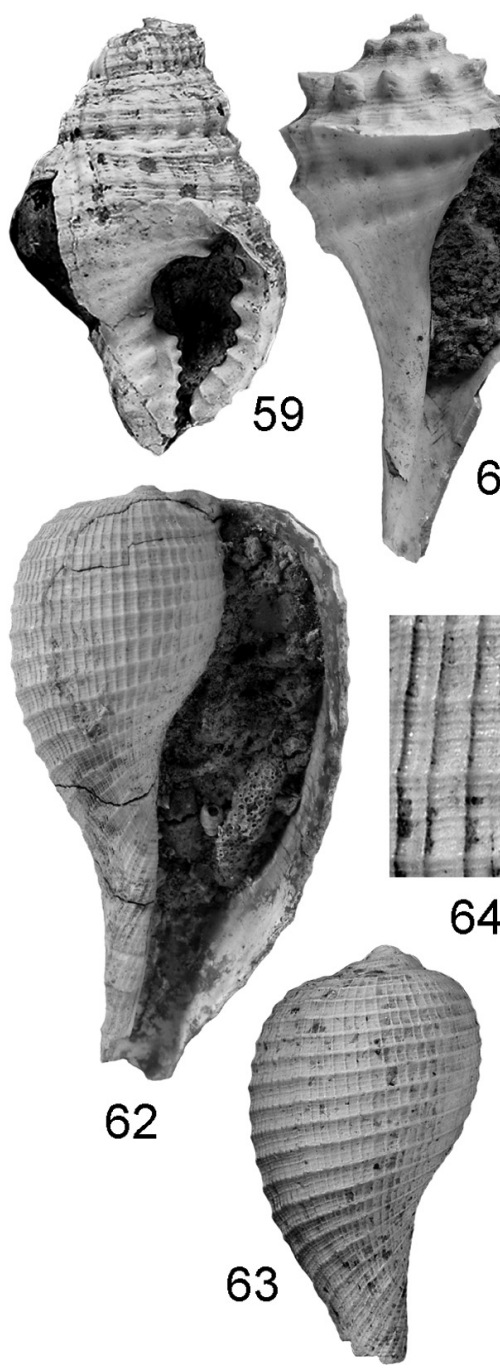
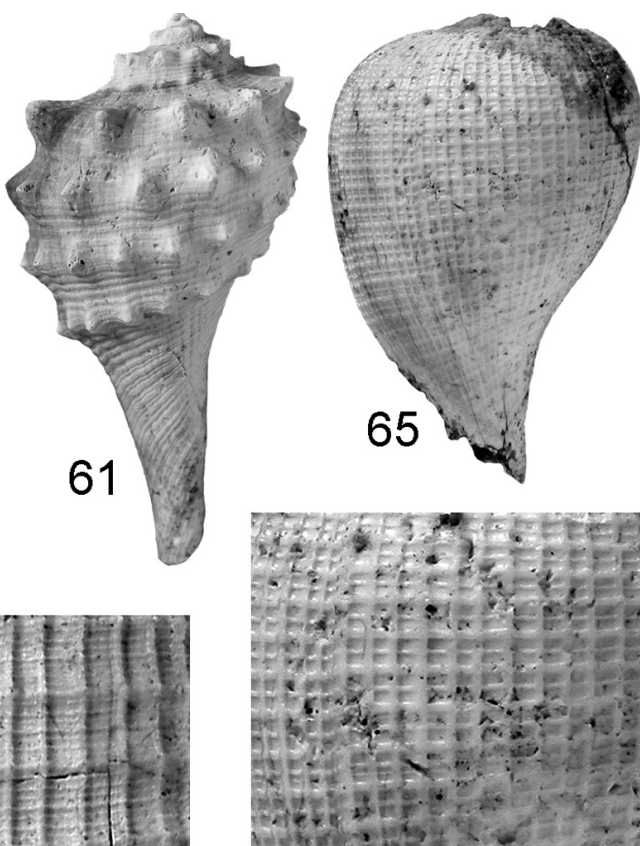

66

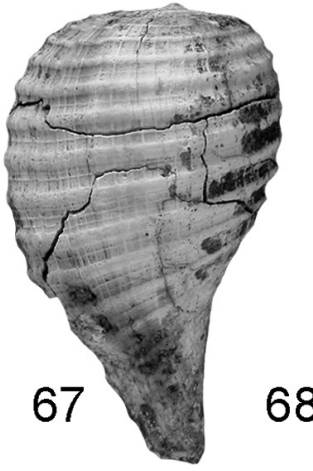

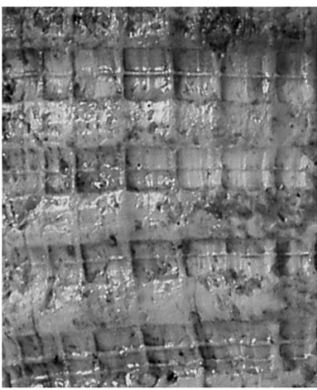

Fig. 59. Personopsis grasi (Bellardi in d'Ancona), Coll. TH, SL 20, MD $13(2.2 \times)$, apertural view. - Figs 60-61. Ficus burdigalensis (Sowerby), Coll. TH, SL 37, MD 20 (1.5×), apertural and abapertural views. - Figs 62-64. Ficus condita (Brongniart). - 62. Coll. TH, SL 40, MD 23 (1.5×), apertural view. - 63. HNHM INV 2017.692., SL 27, MD 15 (1.5×), abapertural view. - 64. Coll. TH, detail of sculpture. - Figs 65-66. Ficus geometra (Borson). - 65. Coll. TH, SL 31, MD 20 (1.5×), abapertural view. - 66. detail of sculpture. - Figs 67-68. Ficus cingulata (Bronn in HöRnEs). - 67.

Coll. TH, SL 30, MD $18(1.5 \times)$, abapertural view. - 68. Coll. TH, detail of sculpture 
Description - Ficiform shell, convex teleoconch whorls, last whorl constricted at the base. Long, wide aperture, smooth outer lip, straight columella, long, slightly recurved siphonal canal. Reticulate sculpture with narrow primary spiral cords (more than 30 on last whorl) and one secondary cord in each interspace, and axial ribs as strong as the primaries.

Remarks - The species differs in morphology from $F$. condita and F. cingulata by regular reticulate sculpture.

Distribution - Middle Miocene: PMS (Italy), NSB (Denmark), Burdigalian: NSB (Germany), Paratethys (Switzerland), Eggenburgian: CP (Slovakia), Badenian: CP (Austria, Hungary, Poland, Romania), Tortonian: PMS (Italy). For Pliocene range see VAN DINGENEN et al. (2016).

\section{Ficus cingulata (Bronn in Hörnes, 1856)}

(Figs 67-68)

1856 Pyrula cingulata Bronn - HöRnEs, p. 676, pl. 28, figs 1-3.

1954 Pirula (Ficus) condita cingulata Bronn - STRAUsz, p. 103, pl. 7, fig. 152.

1969b Pirula cingulata Bronn - Csepreghy-MeZnerics, p. 24, pl. 8, figs 5, 10.

2002 Ficus (Ficus) cingulata Bronn - HARZHAUSER, p. 90, pl. 5, fig. 16 (cum syn.).

Material - 12 specimens (SL 30-64); HNHM: INV 2017.694. (9), three specimens in private collections.

Description - Large, ficiform shell, low spire, protoconch of two convex, smooth whorls, convex teleoconch whorls, last whorl $98 \%$ of the total height, constricted at the base. Long, wide aperture, smooth outer lip, long, slightly recurved siphonal canal. Spiral sculpture of two strong primary and numerous fine secondary cords on sutural ramp of the last whorl, broad, flat primary cords (10-14 on the last whorl) with two secondaries in the interspaces, axial sculpture of fine axial ribs.

Remarks - The species is typical of the Paratethys. It differs in morphology from $F$. condita by larger size, lower spire and broad and flat spiral primary cords.

Distribution - Karpatian-Badenian: CP (Austria, Hungary), Badenian: CP (Bulgaria, Hungary, Poland, Romania).

\section{CONCLUSION}

The Tonnoidea assemblage of Letkés is significant for the high alpha diversity. A material of 1326 specimens was studied from which 22 well-known species and a new species were identified. Four taxa form about $60 \%$ of the material; the most abundant species are Semicassis laevigata (26.5\%), Cassis postmamillaris (12.6\%), Aspa marginata (12\%), and Monoplex corrugatus (9.3\%). The proportion of Semicassis szilviae n. sp. is 1\%, while Eudolium subintermedium and Personopsis grasi 
are present with only a single specimen. The richness of the assemblage can be well demonstrated by the fact that four species (Turritriton grundensis, Bursa ranelloides, B. corrugata, and Personopsis grasi) are new records in Hungary. The assemblage studied here with 23 tonnoids is the richest one both in the country, and in the Middle Miocene Paratethys; aside from the very rare genus Pisanianura Rovereto, all tonnoid species recorded from the Paratethys Province occur at Letkés. (Genus Pisanianura was described from Hungary with a new species, $P$. gaboraroni by CSEPREgHY-MEZNERICS 1969a, however, the taxonomic position of this species has been discussed in the literature, see LANDAU \& HARZHAUSER 2012).

The Ficoidea material is represented by four species from which Ficus condita was the most abundant, while F. burdigalensis and F. geometra appeared with a few specimens only. The occurrence of $F$. burdigalensis is noteworthy, it has been hitherto known only from the Early Miocene. However, acme of several other Early Miocene species [e.g. Tudicla rusticula (Basterot), Melongena cornuta (Agassiz), Ficus cingulata (Bronn in Hö RNEs)] was also typical of the Karpatianearly Badenian in the Central Paratethys (Ćorić et al. 2004).

The high diversity of the Tonnoidea and the Ficoidea corresponds to the Mid-Miocene Climate Optimum, as both are thermophilic superfamilies. The highest number of tonnoid species in the Central Paratethys was recorded from the early Badenian (LANDAU et al. 2009). The acme was the result of the immigration of thermophilic molluscs from the Mediterranean. Similar high diversity was observed in the Conidae assemblage of Letkés (Kovács \& Vicián 2014; HARzhauser \& LANDAU 2016), and both the Cypraeidea and the Muricoidea faunas of the locality are also characterized by an outstanding richness (researches of these superfamilies are in progress).

Acknowledgements - The authors are indebted to Miklós Kázmér (Eötvös University, Budapest) and Alfréd Dulai (Hungarian Natural History Museum, Budapest) for professional help. Constructive review by Giulio Pavia (Italy) helped to improve the manuscript. Gerhard Stein (Germany) helped our work with photographs. Tamás Hirmetzl, Helmut Krock, Tamás Németh and Orsolya Székelyhidi kindly offered their gastropod materials for study. We thank Anton and Thomas Breitenberger for donation of a C. cypraeiformis specimen to the collection of the HNHM. We are also grateful to the staff of the Geological Library of the Mining and Geological Survey of Hungary.

\section{REFERENCES}

Ancona C. D’ 1872: Malacologia Pliocenica Italiana II. Generi: Pisania, Ranella, Triton, Fasciolaria, Turbinella, Cancellaria, Fusus. - Memorie per servire alla descrizione della Carta Geologica d'Italia 2: 55-141.

Atanacković M. A. 1985: Mekušci morskog miocena Bosne. - Geoinženjering, Sarajevo, 308 pp. 
BA£U K W. 1995: Middle Miocene (Badenian) gastropods from Korytnica, Poland; Part II. - Acta Geologica Polonica 45(3-4): 153-255.

Bohn-Havas M. 1973: A Keleti-Mecsek torton Mollusca faunája. (Tortonische Molluskenfauna des Östlichen Mecsek-Gebirges.) - Jahrbuch der Ungarischen Geologischen Anstalt 53(4): 951-1079, (1081-1161).

BoetTGer O. 1906: Zur Kenntnis der Fauna der mittelmiozanen Schichten von Kostej im KrassoSzorenyer Komitat. III. - Verhandlungen und Mitteilungen des siebenbürgischen Vereines für Naturwissenschaften zu Hermannstadt 54: 1-99.

Borson S. 1820-1825: Saggio di Orittografia Piemontese. - Memorie della Reale Academia di Scienze di Torino 25(1820): 180-229, 26(1821): 297-367, 29(1825): 251-318.

BoRzA T. 1973: Rétegtani és őslénytani vizsgálatok Hont (É-Börzsöny) környékén. (Stratigraphical and paleontological investigations in the vicinity of Hont (northern Börzsöny Mountains).) - Földtani Közlöny 103(1): 27-40. (in Hungarian with English abstract)

Brocchi G. 1814: Conchiologia fossile subapennina, con osservazioni geologiche sugli Apennini e sul suolo adiacente, 1-2. - Stamperia Reale, Milano, 712 pp. https://doi.org/10.5962/bhl.title.11569

BrongNiart A. 1823: Mémoire sur les terrains de sédiment supérieurs calcaréo-trappéens du Vicentin. - Levrault, Paris, 86 pp. http://dx.doi.org/10.5962/bhl.title.9097

Ćorić S., Harzhauser M., Hohenegger J., Mandic O., Pervesler P., Roetzel R., Rögl F.,

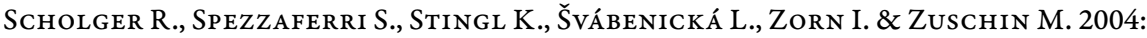
Stratigraphy and correlation of the Grund Formation in the Molasse Basin, Northeastern Austria (Middle Miocene, Lower Badenian). - Geologica Carpathica 55(2): 207-215.

Csepreghy-Meznerics I. 1956: A szobi és letkési puhatestü fauna. (Die Molluskenfauna von Szob und Letkés.) - Jahrbuch der Ungarischen Geologischen Anstalt 45(2): 363-477.

CSEPREGHY-MEZNERICS I. 1969a: Nouvelles Gastropodes et Lamellibranches pour la faune hongroise des gisements tortoniens-inférieurs de la Montagne de Bükk. - Annales historico-naturales Musei nationalis hungarici, Pars Mineralogica et Palaeontologica 61: 63-127.

CsePreghy-Meznerics I. 1969b: La faune tortonienne-inférieure des gisements tufiques de la Montagne de Bükk: Gastropodes I. - Egri Múzeum Évkönyve 7: 17-34.

DefrANCE M. J. L. 1817 [in 1816-1830]: In: Cuvier F. (ed.): Dictionnaire des sciences naturelles. Levrault, Strasbourg \& Le Normant, Paris, pp: 1-60.

EIch Wald E. 1830: Naturhistorische Skizze von Lithauen, Volhynien und Podolien in GeognostischMineralogischer, Botanischer und Zoologischer Hinsicht. - Zawadzki, Wilna, 256 pp.

Ferrero Mortara E., Montefameglio l., Novelli M., Opesso G., Pavia G. \& Tampieri R. 1984: Catalogo dei tipi e degli esemplari figurati della collezione Bellardi e Sacco. II. - Museo Regionale di Scienze Naturali, Torino, 484 pp.

FranzenAu A. 1897: Adatok Letkés faunájához. [Some data to the fauna of Letkés.] - Mathematikai és Természettudományi Közlemények 26: 3-36.

Gmelin J. F. 1791: Caroli a Linné Systema Naturae per Regna Tria Naturae. Tomus 1, pars 6, Vermes. - Delamolliere, Lugduni, 3021-3910.

Grateloup J.-P. S. 1847: Conchyliologie fossile des terrains tertiaires du basin de l'Adour I., Univalves, Atlas. - Lafargue, Bordeaux, Ranella, Triton, Murex, pls 29-31.

Harzhauser M. 2002: Marine und brachyhaline Gastropoden aus dem Karpatium des Korneuburger Beckens und der Kreuzstettener Bucht (Österreich, Untermiozän). - Beiträge zur Paläontologie 27: 61-159.

Harzhauser M. \& Landau B. 2016: A revision of the Neogene Conidae and Conorbidae (Gastropoda) of the Paratethys Sea. - Zootaxa 4210(1): 178 pp.

https://doi.org/10.11646/zootaxa.4210.1.1 
Hinculov L. 1968: Fauna miocenă din Bazinul Mehadia. - In: IlıEscu O., Hinculov A. \& HiNCulov L.: Bazinul Mehadia, Studiul geologic şi paleontologic. - Memorii Institutul Geologic 9: 75-201.

Hoernes R. \& Auinger M. 1884: Die Gasteropoden der Meeres-Ablagerungen der ersten und zweiten Miocänen Mediterran-Stufe in der Österreichisch-Ungarischen Monarchie. - $A b$ handlungen der Kaiserlich-Königlichen geologischen Reichsanstalt 12: 153-192, pls 17-22.

Hörnes M. 1851-1870: Die fossilen Mollusken des Tertiär-Beckens von Wien. - Abhandlungen der Kaiserlich-Königlichen Geologischen Reichsanstalt, 3-4: 1-42, pls 1-5 (1851), 43-208, pls 6-20 (1852), 209-296, pls 21-32 (1853), 297-382, pls 33-40 (1854), 383-460, pls 41-45 (1855), 461-736, pls 46-52 (1856) (3); 1-479, pls 1-85 (1870) (4).

Kojumdgieva E. 1960: Le Tortonien du type viennois. - In: Kojumdgieva E. \& Strachimirov B.: Les fossiles de Bulgarie, VII, Tortonien, pp. 1-246. - Academie des Sciences de Bulgarie, Sofia, $317 \mathrm{pp}$.

KóKAY J. 1966: Geologische und paläontologische Untersuchung des Braunkohlengebietes von Herend - Márkó (Bakony-Gebirge, Ungarn). - Geologica Hungarica, Series Palaeontologica 36: $1-147$.

Kovács Z. \& Vicián Z. 2014: Badenian (Middle Miocene) Conoidean (Neogastropoda) fauna from Letkés (N Hungary). - Fragmenta Palaeontologica Hungarica 30(2013): 53-100.

Lamarck J. B. P. A. De M. 1803: Sur les fossiles des environs de Paris. - Annales du Muséum National d'Histoire Naturelle de Paris 2: 217-227.

LAMARCK J. B. P. A. DE M. 1816: Tableau encyclopédique et méthodique des trois règnes de la nature. 23. Mollusques et polypes divers. Liste des objets représentés dans les planches de cette livraison. - Agasse, Paris, 16 pp.

Landau B., Beu A. \& Marquet R. 2004: The Early Pliocene Gastropoda (Mollusca) of Estepona, Southern Spain Part 5: Tonnoidea, Ficoidea. - Palaeontos 5: 35-102.

LANDAU B. \& HARZHAUSER M. 2012: An addition to the tonnoidean gastropods of the middle Miocene Paratethys: the genus Pisanianura Rovereto, 1899. - Cainozoic Research 9(1): 135-137.

Landau B. M., Harzhauser M. \& Beu A. 2009: A revision of the Tonnoidea (Caenogastropoda, Gastropoda) from the Miocene Paratethys and their palaeobiogeographic implications. Jabrbuch der Geologischen Bundesanstalt 149(1): 61-109.

LANDAu B. M., Harzhauser M., İslamoĞLU Y. \& Silva C. M. 2013: Systematics and palaeobiogeography of the gastropods of the middle Miocene (Serravallian) Karaman Basin, Turkey. - Cainozoic Research 11-13: 1-584.

LINNAEUS C. 1758. Systema naturae per regna tria naturae, secundum classes, ordines, genera, species, cum characteribus, differentiis, synonymis, locis. 1. Editio decima, reformata. - Laurentii Salvii, Holmiae, 824 pp.

Lozouet P., Lesport J.-F. \& Renard P. 2001: Révision des Gastropoda (Mollusca) du Stratotype de l'Aquitanien (Miocène inf.): site de Saucats "Lariey", Gironde, France. - Cossmannia, Hors-série 3, GERMC, 190 pp.

Nagymarosy A. \& Hámor G. 2012: Genesis and Evolution of the Pannonian Basin. - In: HaAs J. (ed.): Geology of Hungary, pp: 149-200, Springer, Berlin-Heidelberg. https://doi.org/10.1007/978-3-642-21910-8

Noszky J. 1925: Beiträge zur Fauna der Ungarischen Leithakalkbildungen. - Annales Musei Nationalis Hungarici, Pars Mineralogica, Geologica, Palaeontologica 22: 230-280.

Noszky J. 1940: A Cserháthegység földtani viszonyai. (Die Geologie des Cserhát-Gebirges.) - Geologische Beschreibung Ungarische Landschaften 3: 1-178, (179-283). 
ORBIGNY A. D' 1852: Prodrome de paléontologie stratigraphique universelle des animaux mollusques et rayonnés, faisant suite au cours élémentaire de paléontologie et de géologie stratigraphique, 3. - Paris (Victor Masson): 196 pp., index 189 pp. https://doi.org/10.5962/bhl.title.45605

Perry G. 1811: Conchology, or the natural history of shells. - Miller, London, 4 pp., 61 pls.

Pfister T. \& Wegmüller U. 2007: Gastropoden aus den Belpberg-Schichten (Obere Meeresmolasse, mittleres Burdigalium) bei Bern, Schweiz. 2. Teil: Tonnoidea bis Architectonicoidea. - Archiv für Molluskenkunde 136(2): 151-209.

Popa M. V., Duma A. \& SĂPLĂCAN A. 2015: Badenian gastropods from the collections of the Mureş County Museum. - Analele Stiintificeale Universitatii "Al. I. Cuza" din Iasi Seria Geologie 60(2) (2014): 5-30.

ReEve L. A. 1844: Monograph of the genus Triton. - In: Conchologia Iconica, Vol. 2, Reeve, London, Pls 1-20.

SACco F. 1890: I Molluschi dei terreni terziarii del Piemonte e della Liguria. Parte 7. - Clausen, Torino, 96 pp. http://dx.doi.org/10.5962/bhl.title.12269

SAssi A. 1827: Saggio geologico sopra il Bacino terziario di Albenga. - Giornale Ligustico di Scienze, Lettere ed Arti 1: 467-484.

Sowerby G. B. 1820-1834: The Genera of Recent and Fossil Shells, for the use of students in Conchology and Geology, part 24: Pyrula. - Stirling, London, 267 pls. https://doi.org/10.5962/bhl.title.86281

Stein G., Moths H., Albrecht F., Havekost U. \& Fehse D. 2016: Revision der miozänen Molluskenfauna (Hemmoorium) von Werder bei Achim (Nordwest-Niedersachsen). Palaeofocus 5: 1-289.

STRAUSz L. 1954: Várpalotai felsö-mediterrán csigák. (Les gastropodes du Méditerranéen supérieur (Tortonien) de Várpalota.) - Geologica Hungarica, Series Palaeontologica 25: 1-84, (87-129).

STRAusz L. 1966: Die miozän-mediterranen Gastropoden Ungarns. - Akadémiai Kiadó, Budapest, $692 \mathrm{pp}$.

Van Dingenen F., Ceulemans L. \& Landau B. M. 2016: The lower Pliocene gastropods of Le Pigeon Blanc (Loire-Atlantique, north west France), 2. Caenogastropoda. - Cainozoic Research 16(2): 109-219.

Vicí́n Z., KRоCK H. \& KovÁcs Z. 2017: New gastropod records from the Cenozoic of Hungary. - Földtani Közlöny 147(3): 265-282. https://doi.org/10.23928/foldt.kozl.2017.147.3.265 